\title{
Impact of Parenting Styles on Adolescents' Self-Esteem and Internalization of Values in Spain
}

\author{
Isabel Martínez ${ }^{1}$ and José Fernando García ${ }^{2}$ \\ ${ }^{1}$ Universidad de Castilla-La Mancha \\ ${ }^{2}$ Universidad de Valencia
}

\begin{abstract}
The relationship of parenting styles with adolescents' outcomes was analyzed within a sample of Spanish adolescents. A sample of 1456 teenagers from 13 to 16 years of age, of whom 54.3\% were females, reported on their parents' child-rearing practices. The teenagers' parents were classified into one of four groups (authoritative, authoritarian, indulgent, or neglectful). The adolescents were then contrasted on two different outcomes: (1) priority given to Schwartz's selftranscendence (universalism and benevolence) and conservation (security, conformity, and tradition) values and (2) level of self-esteem (appraised in five domains: academic, social, emotional, family and physical). The results show that Spanish adolescents from indulgent households have the same or better outcomes than adolescents from authoritative homes. Parenting is related with two self-esteem dimensions-academic and family — and with all the self-transcendence and conservation values. Adolescents of indulgent parents show highest scores in self-esteem whereas adolescents from authoritarian parents obtain the worst results. In contrast, there were no differences between the priority given by adolescents of authoritative and indulgent parents to any of the selftranscendence and conservation values, whereas adolescents of authoritarian and neglectful parents, in general, assign the lowest priority to all of these values.
\end{abstract}

Keywords: parenting, self-esteem, self-transcendence values, conservation values

La relación entre los estilos de socialización parental y sus efectos en los adolescentes se ha analizado con jóvenes españoles. Se midieron las practicas de socialización de los padres en una muestra de 1456 adolescentes de 13 a 16 años, de los cuales el 54,3\% eran chicas. Los padres fueron clasificados en cuatro grupos diferentes (autorizativos, autoritarios, indulgentes y negligentes). Se analizaron las puntuaciones de los adolescentes en dos variables diferentes: (1) la prioridad que los adolescentes daban a los valores de auto-trascendencia (universalismo y benevolencia) y conservación (seguridad, conformidad y tradición) de Schwartz y (2) la autoestima de los adolescentes (medida con cinco dominios: académico, social, emocional, familiar y físico). Los resultados muestran que los adolescentes españoles de hogares indulgentes consiguen los mismos o mejores resultados que los adolescentes educados en familias autorizativas. Los estilos de socialización se relacionan con dos dimensiones de la autoestima-académica y familiar-y con todos los valores de auto-trascendencia y conservación. Los hijos de padres indulgentes obtienen las mayores puntuaciones en autoestima, mientras que los hijos de padres autoritarios obtienen los peores resultados. Por otra parte, no se dan diferencias en la prioridad que los hijos de padres autorizativos e indulgentes dan a los valores de auto-trascendencia y conservación, mientras que los hijos de padres autoritarios y negligentes son los que asignan, en general, la menor prioridad a todos estos valores.

Palabras clave: socialización parental, autoestima, valores de auto-trascendencia, valores de conservación

Correspondence concerning this article should be addressed to Isabel Martínez. Universidad de Castilla-La Mancha, Departamento de Psicología, Avda. de los Alfares, 44, 16071- Cuenca (Spain). Tel: +34-969179100. Fax: +34-969179107. E-mail: MIsabel.Martinez@uclm.es 
To analyze the association of parenting with adolescents' outcomes, two orthogonal constructs of parenting have traditionally been considered: Demandingness and Responsiveness (Baumrind, 1989, 1991; Bersabé, Fuentes, \& Motrico, 2001; Maccoby \& Martin, 1983; Musitu \& García, 2004; Villalobos, Cruz, \& Sánchez, 2004). Demandingness refers to the extent to which parents make control, supervision and maturity demands in their parenting. Whereas responsiveness refers to the extent to which parents show their children warmth and acceptance, give them support and reason with them. Based on these two dimensions, four parenting styles have been identified (Baumrind, 1991; Lamborn, Mounts, Steinberg, \& Dornbusch, 1991; Maccoby \& Martin, 1983; Musitu \& García, 2004; Steinberg, Lamborn, Darling, Mounts, \& Dornbusch, 1994; Villalobos et al., 2004): authoritative (parents who are high on both demandingness and responsiveness), indulgent (parents who are low on demandingness and high on responsiveness), authoritarian (parents who are high on demandingness and low on responsiveness), and neglectful (parents who are low on both demandingness and responsiveness).

In this study, we examine the associations of parenting styles with adolescents' self-esteem and internalization of values in a sample of Spanish adolescents. Both, internalization of social values and the development of the child's self-esteem, are central objectives of parental socialization (see Grusec \& Goodnow, 1994). Self-esteem has been one of the traditional measures of adolescent adjustment in parenting studies (e.g., Amato \& Fowler, 2002; Barber, 1990; Barber, Chadwick, \& Oerter, 1992; Cava, Musitu, \& Murgui, 2006; Coopersmith, 1967; Felson \& Zielinsky, 1989; Gecas \& Schwalbe, 1986; Rudy \& Grusec, 2006). However, with few exceptions (e.g., Aluja, del Barrio, $\&$ Garcia, 2005), the internalization of values as an outcome variable has not been purposely analyzed, even though different authors have stressed the importance of parenting styles in children's internalization of social values (Grusec \& Goodnow, 1994; Grusec, Goodnow, \& Kuczynski, 2000; MacDonald, 1997; Rudy \& Grusec, 2001). Internalization, referring to "taking over the values and attitudes of society as one's own so that socially acceptable behavior is motivated not by anticipation of external consequences but by intrinsic or internal factors" (Grusec \& Goodnow, 1994, p. 4) has been pointed out as the key of well-developed children (e.g., Baumrind, 1966, 1978; 1983; Lewis, 1981). Grusec and Goodnow suggest that internalization should be measured in terms of prosocial behavior-consideration for the feelings or needs of others-and moral standardsassessed, for instance, by resistance to temptation, reparation after deviation, evidence of guilt, and level of moral reasoning. Moreover, these authors recommend taking into account other variables of psychological adjustment, such as self-esteem, that are required for the internalization of values; according to them, low self-esteem can be an impediment to internalization because it "could lead to a reduction on the child's part in standards for acceptable behavior and interfere with internalization" (Grusec \& Goodnow, 1994, p. 17).

Considering the internalization of values in terms of prosocial behavior and moral standards, the present study focuses on the impact of parenting on Schwartz's selftranscendence and conservation values (Schwartz, 1992; Schwartz \& Bilsky, 1987, 1990) in adolescents. These values are centered on consideration for others and acceptance of social norms. Self-transcendence values emphasize concern for the welfare and interests of others; they include universalism-referring to understanding, appreciation, tolerance, and protection of the welfare of all people and of nature-and benevolence - in reference to preserving and enhancing the welfare of people with whom one is in frequent personal contact. Conservation values emphasize order, harmony, self-restriction, and non-threatening relations; they include security - referring to safety, harmony, and stability of society, of relationships, and of self-, conformityreferring to restraint of actions, inclinations, and impulses likely to upset or harm others and violate social expectations or norms-, and tradition-meaning respect, commitment, and acceptance of the customs and ideas provided by traditional culture or religion (Sagiv \& Schwartz, 2000; Schwartz, 1994, 2005; Schwartz \& Bilsky, 1987, 1990).

Research on parent-adolescent relationships has consistently reported that adolescents from EuropeanAmerican families, raised in authoritative families in the United States, have higher psychosocial competence and lower psychological and behavioral dysfunctions than adolescents from authoritarian, indulgent, and neglectful homes (Lamborn et al., 1991; Maccoby \& Martin, 1983; Steinberg et al., 1994). The results of these researches have confirmed that high levels of parental warmth, responsiveness, and involvement combined with high levels of strictness, foster optimal adjustment in Euro-American children, offering emotional support by means of responsiveness and establishing adequate guidelines and limits to control children's behavior by means of demandingness.

However, parenting research has revealed some differences across cultures and ethnic groups (e.g., Chao, 1994; Wahler \& Cerezo, 2005). For example, among African and Asian-American adolescents, no complete evidence has been found of the positive influence of authoritative parenting (Dornbusch, Ritter, Leiderman, Roberts, \& Fraleigh, 1987; Steinberg, Dornbusch, \& Brown, 1992). In fact, Chao (2001) has shown that Asian-American adolescents raised in authoritarian households do not do worse at school than adolescents raised in authoritative homes. Quoss and Zhao (1995) also found that authoritarian parenting-but not authoritative-predicts satisfaction with the parent-child relationship in Chinese children, whereas Dwairy, Achoui, Abouserie and Farah (2006) have found that in Arab societies, 
authoritarian parenting does not harm the adolescents' mental health as it does in Western societies. Furthermore, other researches have found no differences between indulgent and authoritative parenting in the offspring's outcomes in certain contexts and cultures. This is the case for Korean-American adolescents raised by authoritative fathers, who do not have better academic achievement than youths raised by indulgent fathers (Kim \& Rhoner, 2002). Also in Mexico, Villalobos et al. (2004) have shown that adolescents from authoritative and indulgent families obtain higher scores than adolescents from neglectful families on diverse measures of competence and adjustment; but there were no differences between authoritative and indulgent parenting. Finally, in Italy and Brazil, studies measuring the impact of parenting on selfesteem have illustrated that adolescents from indulgent homes have similar or higher self-esteem than adolescents from authoritative households (Marchetti, 1997; Martínez, 2003; Musitu \& Garcia, 2004).

To explain the cross-cultural discrepancies in the association between parental practices and adolescents' outcomes, several authors have suggested that the meaning of socialization practices can differ depending of the cultural context (Chao, 1994; Grusec, Rudy, \& Martini, 1997; Pels \& De Haan, 2007; Rodd, 1996). For example, Rudy and Grusec (2001) indicated that strictness practices, which involve a hierarchical parent-child relationship, are linked with positive cognitions and affect in contexts that emphasize hierarchical relations and respect for authority. According to this perspective, parental strictness would not be effective in countries characterized by horizontal collectivism (Triandis, 1995, 2001), like Spain (Gouveia, Clemente, \& Espinosa, 2003), where equalitarian relations, instead of hierarchical ones, are emphasized. On the contrary, high levels of reasoning, parental affection, acceptance, and involvement would be enough to obtain optimal adolescent adjustment in Spain, without the need of high levels of strictness.

The purpose of this study is to examine the relation between parenting styles and (a) adolescents' self-esteem, appraised with five specific components-academic, social, emotional, family, and physical (Byrne \& Shavelson, 1996; Shavelson, Hubner, \& Stanton, 1976) —on the one hand, and (b) adolescents' internalization of Schwartz's values (Schwartz, 1992; Schwartz \& Bilsky, 1987, 1990) of self-transcendenceuniversalism and benevolence - and conservation - security, conformity and tradition — on the other hand. This purpose is important because the results of several studies have suggested that the beneficial impact of authoritative parenting observed in the United States is not confirmed in all cultures (e.g., Chao, 1994, 2001; Darling \& Steinberg, 1993; Dornbusch et al., 1987; Dwairy et al., 2006; Kim \& Rhoner, 2002; Musitu \& García, 2004; Quoss \& Zhao, 1995; Steinberg, Mounts, Lamborn, \& Dornbusch, 1991).

As the Spanish culture is characterized by equalitarian relations (Gouveia et al., 2003), where strictness practices seem to not be effective (Mayseless, Scharf, \& Sholt, 2003;
Rudy \& Grusec, 2001), and previous studies in Spain have shown, within a large sample of age, that adolescents from indulgent parents reach equal or higher scores in self-esteem than adolescents from authoritative parents (Musitu \& García, 2004), we expect that adolescents of a younger age range who perceive their parents as indulgent would show higher or equal levels of self-esteem than would adolescents who perceive their parents as authoritative. Taking into account that low self-esteem has been theorized to interfere with internalization (Grusec \& Goodnow, 1994), and that the internalization of values is also an indicator of adolescent adjustment (Feldman \& Rosenthal, 1991; Grusec \& Goodnow, 1994), we anticipate that Spanish adolescents from indulgent homes will give higher or similar priority to self-transcendence and conservation values than will adolescents who perceive their parents as authoritative.

\section{Method}

\section{Participants}

Our sampling frame consisted of a complete list of all public $(90 \%)$ and private $(10 \%)$ centers - Spanish private schools financed by the government "centros concertados" were excluded to maximize the variance explained (Kerlinger, 1973)__" from middle-class backgrounds of a large metropolitan area in Spain with over one million inhabitants. We chose multistage cluster sampling because it provides a feasible sampling solution, given our available list of educational centers, by allowing us to randomly sample clusters. Kalton (1983) reported that if clusters are selected randomly, then the elements within the clusters (i.e., students) are similarly selected in a random method. A priori power analysis determined that 1424 participants were required to detect an unfavorable small effect size $(f=.10)$ with a power of $.90(\alpha=.05,1-\beta=.90)$ in $F$-test between the four parenting styles (Erdfelder, Faul, \& Buchner, 1996).

To achieve the a priori-determined sample size of 1424 students, we contacted the director of each school using our ram-list of educational centers (two public centers refused to participate). We intentionally over-sampled, randomly selecting over 1650 potential participants who: (a) were Spanish, as were their parents and four grandparents; (b) lived in two-parent nuclear families, mother or primary female caregiver and father or primary male caregiver; (c) had received their parents' permission to participate; and (d) were attending school at the time the research was done. A total of 1456 students completed the instruments $(88 \%$ response rate). The power of any $F$-test between the four parenting styles $(f=.10 ; \alpha=.05)$ was .91 (Erdfelder et al., 1996). The sample came from eight public schools $(89.1 \%)$ and two private schools. Of the sample, $54.3 \%$ were females and $45.7 \%$ males, age range was $13-16$ years $(M=14.6$ years, $S D=13.2$ months). 


\section{Measures}

Parental Socialization Scale (ESPA29; Musitu \& García, 2001). Adolescents reported the frequency of several parental practices (fathers' and mothers' practices were asked about separately) in different situations with significant impact on the parent-child relationship in Western culture. Twentynine situations were sampled, 13 teenagers' compliance situations (e.g., "If somebody comes over to visit and I behave nicely") and 16 teenagers' noncompliance situations (e.g., "If I break or ruin something at home") to assess parental practices with a 4-point Likert-type scale $(1=$ never, $4=$ always $)$. In each of the 13 compliance situations, offspring had to rate the parenting practices of affection ("he/she shows affection") and indifference ("he/she seems indifferent"). In each of the 16 noncompliance situations, offspring had to rate the parenting practices of dialogue ("he/she talks to me"), detachment ("it's the same to him/her"), verbal scolding ("he/she scolds me"), physical punishment ("he/she spanks me"), and revoking privileges ("he/she takes something away from me"). The family score for the acceptance/involvement dimension was obtained by averaging the responses on affection, dialogue, indifference, and detachment practices of both father and mother (in the last two practices, the scores were inverted because they are inversely related to the dimension). The family score for the strictness/imposition dimension was obtained by averaging the responses on verbal scolding, physical punishment and revoking privileges practices of both the father and the mother. Hence, two dimensions measured family parental styles (see Lamborn et al., 1991; Steinberg et al., 1994) so that higher scores represent a greater sense of acceptance/involvement and strictness/imposition (highest score on the two scales $=4$ ).

This scale was originally validated in Spain with a sample of almost 3,000 adolescents (Musitu \& García, 2001) between the ages of 10 and 18 years (2,009 of whom were between 13-16 years of age) and was developed to specifically assess the four types of parenting styles: authoritative, authoritarian, indulgent, and neglectful (Marchetti, 1997; Martínez, Musitu, García, \& Camino, 2003; Musitu \& García, 2001, 2004). Following the examples of Lamborn et al. (1991) and Steinberg et al. (1994), the four parenting categories (authoritative, indulgent, authoritarian, and neglectful) are defined by trichotomizing the sample with a tertile split on each dimension (acceptance/involvement and strictness/imposition) and examining the two variables simultaneously. Research indicates that similar results are obtained by dichotomizing the sample using median split procedures (see Chao, 2001; Kremers, Brug, de Vries, \& Engels, 2003) and Musitu and García (2001) suggest splitting the sample after controlling the differences for sex and age. Furthermore, in the ESPA29, the parenting styles were evaluated from both contextual (Darling \& Steinberg, 1993) and situational (Smetana, 1995) perspectives where a total of 232 questions were asked, 116 for each parent. The factorial structure of the instrument was confirmed in various studies (Llinares, 1998; Musitu \& García, 2001). Cronbach's alpha for all 232 items was $\alpha=.96$; and for each dimension: acceptance/involvement, $\alpha=.97$, and strictness/imposition, $\alpha=.96$; and for each subscale: affection, $\alpha=.96$; indifference, $\alpha=.95$; dialogue, $\alpha=.95$; detachment, $\alpha=$ .90; verbal scolding, $\alpha=.94$; physical punishment, $\alpha=.93$; and revoking privileges, $\alpha=.96$.

Outcome variables. Adolescents' personal adjustment was measured with the Multidimensional Self-Esteem Scale (AF5; García \& Musitu, 1999). This 30-item scale assesses self-esteem in five domains: academic (e.g., "I do my homework well"), social (e.g., "I make friends easily"), emotional (e.g., reverse scored, "Many things make me nervous"), family (e.g., "I feel that my parents love me"), and physical (e.g., "I take good care of my physical health"). Each domain is measured with 6 items (99-point scale); modifications were made to obtain domain scores ranging from .1 to 9.99 (García \& Musitu, 1999). The factorial structure of the instrument was confirmed both with exploratory (García \& Musitu, 1999, Martínez, 2003) and confirmatory (García, Musitu, \& Veiga, 2006; Tomás \& Oliver, 2004) factor analyses, and no method effect appears to be associated with negatively worded items (Tomás \& Oliver, 2004).

The AF5 was previously validated with a sample of 6,500 Spanish subjects (García \& Musitu, 1999) and is more comprehensive than the tools used by most of the studies. For example, the shorter Rosenberg's Self-Esteem scale (Rosenberg, 1965) contains only 10 or 15 items and it have not been normed in Spain (Gual, Pérez-Gaspar, Martínez-Gonzélez, Lahortiga, de Irala-Estevez, \& CerveraEnguix, 2002; Martínez-González, Gual, Lahortiga, Alonso, de Irala-Estevez, \& Cervera, 2003). In the AF5 scale, selfesteem is understood as multidimensional, hierarchically ordered, and increasingly differentiated with age based on the Shavelson and colleagues' theoretical model (Byrne \& Shavelson, 1996; Shavelson et al., 1976). Cronbach's alpha for all items was .83 and for each factor, it was: academic, $\alpha=.90$; social, $\alpha=.74$; emotional, $\alpha=.73$; family, $\alpha=.81$; and physical, $\alpha=.76$.

Adolescents' values of self-transcendence (universalism and benevolence) and conservation (tradition, conformity, and security) were measured with the Schwartz (1992) Value Inventory, adapted from Struch, Schwartz, and van der Kloot, (2002). Each of the 27 items, measuring self-transcendence and conservation values, consists of one single value accompanied by a short descriptive phrase. The participants rated the importance of each value as a guiding principle in their life using a 99-point rating scale coded from 1 (opposed to my values) to 99 (of supreme importance). The average score for the items in the standard indexes was computed to measure the priority given to each of the five motivational types of values used in this study. Modifications 
were made to obtain scored indexes ranging from .1 to 9.99 . Cronbach's alpha for the 27 items was .87 , and for the value indexes as follows: universalism, $\alpha=.74$; benevolence, $\alpha$ $=.73$; conformity, $\alpha=.69$; tradition, $\alpha=.44$; and security, $\alpha=.50$. These reliabilities were within the range of variation commonly observed in these value types (e.g., Roccas, Sagiv, Schwartz, \& Knafo, 2002). Schwartz's Values Inventory was meant to test the Theory of Human Values (Schwartz \& Bilsky, 1987) in more than 200 samples from over 60 countries (Schwartz, 1992; Schwartz \& Sagiv, 1995). All of the 10 value types have also been used to explain a wide range of attitudes and behaviors in many countries (Schwartz \& Bardi, 2001).

\section{Design and Data Analysis}

Design. We used a block design with three demographic controls (adolescents' gender, age, and type of school). These control variables are traditionally used in parenting studies (Lamborn et al., 1991; Steinberg et al., 1992; Steinberg et al., 1994) and have been considered possible moderating variables of parenting effects (e.g., Aunola, Stattin, \& Nurmi, 2000; Kelley, Power, \& Wimbush, 1992). Furthermore, these three control variables function to block residual variance (see García, Frías, \& Pascual, 1999; Maxwell \& Delaney, $1990)$ increasing the $F$-test power in the analyses of the differences in adolescents' self-esteem and value priorities between the four parenting categories, the objective of this investigation. The first assumption of the block design is there should be no-interaction of parenting styles with the control variables (adolescents' gender, age, and type of school) in predicting adolescents' outcomes (e.g., Amato \& Fowler, 2002; Aunola, et al., 2000; Lamborn et al., 1991; Steinberg et al., 1994). Any violation of this assumption would question the status of the control variables, because the relation between parenting styles and the outcome variables would be mediated by the control variables. The second assumption of the block design is that the three demographic controls must be related to the two clusters of outcome variables: self-esteem and value priorities of the adolescents. Violation of this assumption would only affect the statistical power of the $F$-test in the differential analyses between the four parenting categories, because the control variables would not reduce the error term.

In relation to the AF5 self-esteem measure, research has shown that boys tend to have higher emotional and physical self-esteem than girls (Garaigordobil, Durá, \& Pérez, 2005; García \& Musitu, 1999), resulting from a higher prevalence of emotional and physical-image problems in women (e.g., Gual et al., 2002; Martínez-González, et al., 2003; Rothenberg, 1997). However, academic self-esteem tends to be higher in girls (Garaigordobil et al., 2005), consistent with women's current higher academic achievement (García \& Musitu, 1999). Previous research found no differences in adolescents' self-esteem between the age groups analyzed in this study (García \& Musitu, 1999), or between adolescents from public or private schools (García \& Musitu, 1999; Musitu \& García, 2001). In relation to the value priorities analyzed in this study, Insa (2003) has shown that, in Spain, according to gender referential schemes, girls give higher priority to self-transcendence values than did boys. Furthermore, it has been shown that priority given to selftranscendence and tradition values descends in midadolescence because of the increase in priority given to opposite values such as autonomy, independence, and openness (Grotevant \& Cooper, 1998; Insa, 2003). Finally, with respect to type of school, Molpeceres (1996) indicated that students from more traditional private centers give higher priority to conservation values.

Data Analysis. A four-way (Parenting style $\times$ Gender $\times$ Age $\times$ Type of school) multivariate analysis of variance (MANOVA) was conducted for each of the two clusters of related outcome variables (self-esteem dimensions and selftranscendence and conservation value priorities), with parenting style (authoritative, indulgent, authoritarian vs. neglectful), gender (girls vs. boys), age (13-14 vs. 15-16 years old), and type of school (public vs. private) as independent variables. As research has shown, our expectation was that the results would vary as a function of parenting style and of the adolescents' gender, age and type of school (Insa, 2003; Musitu \& García, 1999), but no interactions were expected with parenting style (Amato \& Fowler, 2002; Aunola et al., 2000; Lamborn et al., 1991; Steinberg et al., 1994). Univariate $F$ follow-up tests were conducted within the outcome clusters that had multivariate significant overall differences, and significant results on the univariate tests were followed with Bonferroni's comparisons between all possible pairs of means. Given our primary interest in parenting style, we did not focus on the effects of gender, age, or type of school. When such effects were statistically significant, however, we noted them.

\section{Results}

\section{Typologies}

To define parenting style groups, we followed median split procedures, controlling for gender and age. Authoritative families $(n=391)$ were those who scored above the median on both acceptance/involvement and strictness/imposition, whereas neglectful families $(n=387)$ were below the median on both variables. Authoritarian families $(n=341)$ were below the median on acceptance/involvement but above the median on strictness/imposition. Indulgent families $(n=387)$ were above the median on acceptance/involvement but below the median on strictness/imposition. Table 1 provides information about the sizes of each of the four parenting groups as well as each group's mean and standard deviation on the acceptance/involvement and strictness/imposition dimensions. 
Table 1

Numbers of Cases in Parenting Style Groups, and Mean Scores and Standard Deviations on Measures of Parental Dimensions

\begin{tabular}{|c|c|c|c|c|c|}
\hline & \multicolumn{5}{|c|}{ Parenting Style } \\
\hline & Total & Indulgent & Authoritative & Authoritarian & Neglectful \\
\hline Frequency & 1456 & 337 & 391 & 341 & 387 \\
\hline Percent & 100 & 23.1 & 26.9 & 23.4 & 26.6 \\
\hline \multicolumn{6}{|c|}{ Acceptance/Involvement } \\
\hline$M$ & 3.06 & 3.39 & 3.44 & 2.72 & 2.71 \\
\hline$S D$ & .44 & .23 & .23 & .31 & .30 \\
\hline \multicolumn{6}{|c|}{ Strictness/Imposition } \\
\hline$M$ & 1.73 & 1.45 & 2.01 & 2.02 & 1.44 \\
\hline$S D$ & .37 & .19 & .28 & .29 & .19 \\
\hline
\end{tabular}

Note. Scores on the acceptance/involvement and strictness/imposition scales could range from 1 to 4 .

\section{Parenting Styles and Self-Esteem}

Preliminary multivariate analyses. A MANOVA was computed between parenting style, gender, age, and type of school on the five self-esteem dimensions (academic, social, emotional, family, and physical). The results yielded main effects of parenting styles, $\Lambda=.956, F(15,3920.4)=4.33$, $p<.001$, and gender, $\Lambda=.935, F(5,1420)=19.64, p<$ .001 , but no main effects of age, $\Lambda=.995, F(5$, $1420)=1.56, p=.168$, and type of school, $\Lambda=.994, F(5$, $1420)=1.82, p=.106$. No significant interaction effects were found.

Univariate effects of demographic variables. Although not central to this investigation, follow-up univariate analyses (ANOVAs) for gender indicated differences between boys and girls in levels of academic, $F(1,1424)=5.24, p=.022$, emotional, $F(1,1424)=21.77, p<.001$, and physical selfesteem, $F(1,1424)=45.40, p<.001$. Girls $(M=6.16$, $S D=1.97)$ reported higher academic self-esteem than boys $(M=5.72, S D=1.84)$, suggesting that girls have the highest academic achievement. Whereas emotional and physical self-esteem was higher for boys $(M=5.72, S D=1.60$ and $M=6.29, S D=1.70$, respectively) than for girls $(M=4.83$,
$S D=1.80$ and $M=5.26, S D=1.79$, respectively), as a consequence of the lower prevalence of emotional and physical-image problems in men.

Univariate effects of parenting styles. Five follow-up univariate analyses (see Table 2) indicated that parenting styles had statistically significant main effects for academic and family self-esteem dimensions. As shown in Table 2, adolescents from indulgent parents had higher academic self-esteem than did adolescents from the other family types, whereas adolescents from authoritarian families had the lowest level of academic self-esteem. The family self-esteem of adolescents who perceived their parents as indulgent was also higher than that of adolescents who were raised in the other family types. Furthermore, family self-esteem was higher in authoritative homes than in authoritarian and neglectful homes; and adolescents from authoritarian families had the lowest level of family self-esteem. In short, the results showed that although in general, authoritative parenting is associated with higher academic and family self-esteem than authoritarian and neglectful parenting, adolescents from indulgent parents obtain the best scores in these self-esteem dimensions.

Table 2

Means, Standard Deviations (in Brackets), F Values, Probabilities of a Type I Error, and Post Hoc Bonferroni ${ }^{a}$ Procedure for the Four Parenting Style Groups Across Dimensions of Self-Esteem

\begin{tabular}{lccccrr}
\hline \multirow{2}{*}{$\begin{array}{l}\text { Self-Esteem } \\
\text { Dimensions }\end{array}$} & \multicolumn{5}{c}{ Parenting Style } \\
\cline { 2 - 6 } & Indulgent & Authoritative & Authoritarian & Neglectful & $F(3,1424)$ & $p$ \\
\hline Academic & $6.48(1.68)^{1}$ & $6.04(2.03)^{2}$ & $5.47(1.99)^{3}$ & $5.86(1.84)^{2}$ & 3.78 & .010 \\
Social & $7.30(1.40)$ & $7.42(1.31)$ & $7.18(1.51)$ & $7.19(1.30)$ & 0.88 & .452 \\
Emotional & $5.48(1.80)$ & $5.03(1.73)$ & $5.09(1.82)$ & $5.37(1.70)$ & 1.78 & .149 \\
Family & $8.84(.92)^{1}$ & $8.42(1.17)^{2}$ & $7.08(2.03)^{4}$ & $7.85(1.51)^{3}$ & 18.41 & $<.001$ \\
Physical & $5.88(1.73)$ & $5.95(1.82)$ & $5.54(2.02)$ & $5.55(1.70)$ & 1.11 & .344 \\
\hline
\end{tabular}

${ }^{\mathrm{a}} \mathrm{a}=.05 ; 1>2>3>4$ 


\section{Parenting Styles and Internalization of Values}

Preliminary Multivariate Analyses. A MANOVA was computed between parenting style, gender, age, and type of school on adolescents' values of self-transcendence (universalism and benevolence) and conservation (conformity, tradition, and security). The results yielded main effects of parenting styles, $\Lambda=.974, F(15,3920.4)=$ $2.53, p<.001$; gender, $\Lambda=.968, F(5,1420)=9.38, p<$ .001 ; age, $\Lambda=.985, F(5,1420)=4.30, p<.001$; and type of school, $\Lambda=.992, F(5,1420)=2.26, p=.046$. Only the interaction between gender and type of school was significant. $\Lambda=.992, F(5,1420)=2.31, p=.042$, but Bonferroni pair-wise comparisons between combined pairs of means indicated that no differences were statistically significant. Consequently, we only analyzed the significant main effects.

Univariate effects of demographics variables. Although not a primary focus of this investigation, follow-up ANOVAs for age groups indicated differences in self-transcendence values-universalism, $F(1,1424)=10.02, p=.002$, and benevolence, $F(1,1424)=7.50, p=.006$ - and in one of the conservation values: tradition, $F(1,1424)=15.77, p<.001$. Priority to self-transcendence values descended in midadolescence: younger adolescents (13-14 years old) gave higher priority than older adolescents (15-16 years old) to universalism $(M=7.55, S D=1.16$ vs. $M=7.40, S D=1.05)$ and benevolence $(M=7.78, S D=1.18$ vs. $M=7.65$, $S D=1.11)$ values. The same tendency was observed in tradition values, younger adolescents $(M=6.32, S D=1.24)$ gave higher priority than older adolescents $(M=6.01$, $S D=1.20)$. Univariate analysis for gender showed differences in self-transcendence values-universalism, $F(1$, $1424)=16.08, p<.001$, and benevolence, $F(1$, $1424)=16.93, p<.001-$ and in one of the conservation values: security, $F(1,1424)=4.93, p=.027$. Girls gave higher priority than boys to self-transcendence values: benevolence $(M=7.89, S D=1.05$ vs. $M=7.49, S D=1.22)$ and universalism $(M=7.62, S D=1.02$ vs. $M=7.30$, $S D=1.18)$; whereas boys $(M=7.25, S D=1.24)$ gave higher priority than girls $(M=7.20, S D=1.14)$ to security values. Finally, analysis between type of school only showed differences in one of the conservation values: tradition, $F(1$, $1424)=4.23, p=.040$; adolescents from private schools $(M=6.43, S D=1.05)$ assigned higher priority to tradition than adolescents from public schools $(M=6.12, S D=1.24)$.

Univariate effects of parenting styles. Five follow-up ANOVAs indicated that parenting styles had statistically significant main effects on all the self-transcendence and conservation values. With respect to self-transcendence values, as shown in Table 3, adolescents from authoritative homes gave higher priority to universalism values than adolescents from authoritarian and neglectful homes; whereas adolescents from indulgent families scored higher in these values than adolescent from neglectful households. On the other hand, higher priority was given to benevolence values by adolescents raised in authoritative and indulgent families than by adolescents from authoritarian and neglectful homes. With regard to conservation values, the results showed a similar tendency to self-transcendence values. First, adolescents from authoritative and indulgent families gave higher priority to conformity values than adolescents from authoritarian and neglectful families. Second, adolescents from authoritative families gave higher priority to tradition values than those from authoritarian and neglectful families; whereas adolescents from indulgent families assigned higher priority to tradition values than adolescents from neglectful households, who had the lowest score in these values. Finally, adolescents from authoritative parents gave higher priority to security values than adolescents from authoritarian and neglectful families, whereas adolescents from indulgent families scored higher in security values than those from neglectful households. Therefore, in general, authoritative and indulgent parenting was associated with higher adolescents' priority to self-transcendence and conservation values than authoritarian and neglectful parenting.

Table 3

Means, Standard Deviations (in Brackets), F Values, Probabilities of a Type I Error, and Post Hoc Bonferroni ${ }^{a}$ Procedure for the Four Parenting Style Groups Across Adolescents' Value Priorities

\begin{tabular}{lcccccc}
\hline \multirow{2}{*}{$\begin{array}{l}\text { Value } \\
\text { Priorities }\end{array}$} & \multicolumn{5}{c}{ Parenting Style } \\
\cline { 2 - 6 } & Indulgent & Authoritative & Authoritarian & Neglectful & $F(3,1424)$ & $p$ \\
\hline $\begin{array}{l}\text { Self-Transcendence } \\
\quad \text { Universalism }\end{array}$ & $7.60(1.03)^{1}$ & $7.65(1.06)^{1 \mathrm{a}}$ & $7.40(1.17)^{\mathrm{b}}$ & $7.23(1.11)^{2}$ & 5.11 & .002 \\
$\quad$ Benevolence & $7.89(1.05)^{1}$ & $7.89(1.14)^{1}$ & $7.65(1.22)^{2}$ & $7.44(1.12)^{2}$ & 4.44 & .004 \\
Conservation & & & & & \\
$\quad$ Conformity & $7.68(1.22)^{1}$ & $7.81(1.15)^{1}$ & $7.22(1.37)^{2}$ & $7.08(1.18)^{2}$ & 5.81 & $<.001$ \\
$\quad$ Tradition & $6.28(1.17)^{\mathrm{a}}$ & $6.40(1.22)^{1}$ & $6.11(1.23)^{2}$ & $5.86(1.22)^{3 \mathrm{~b}}$ & 4.64 & .003 \\
$\quad$ Security & $7.32(1.11)^{1}$ & $7.52(1.19)^{1 \mathrm{a}}$ & $7.10(1.19)^{\mathrm{b}}$ & $6.96(1.18)^{2}$ & 3.62 & .013 \\
\hline
\end{tabular}

${ }^{\mathrm{a}} \mathrm{a}=.05 ; 1>2>3>4 ; \mathrm{a}>\mathrm{b}$ 


\section{Discussion}

The results support the hypothesis of the study: adolescents from indulgent families achieve the same or higher scores in self-esteem and internalization of selftranscendence and conservation values than adolescents from authoritative families. The findings confirm and extend previous research in Spain (Musitu \& García, 2004); the positive influence of indulgent parenting on adolescents' self-esteem can be generalized to the internalization of values in adolescents. In the two self-esteem dimensions (academic and family) that are related to parenting styles in the study, adolescents from indulgent parents show higher scores than adolescents from authoritative parents. The fact that, in the present study, parenting only relates with two self-esteem dimensions could be due to the age range analyzed. As selfesteem increasingly differentiates with age (Byrne \& Shavelson, 1996; Shavelson et al., 1976), it is possible that the influence of parenting on self-esteem would be easier to appreciate with an older age range. On the other hand, we did not find differences between the priority given by adolescents from authoritative and indulgent parents to any of the self-transcendence and conservation values.

This result suggests that the parents' use of acceptance/ involvement is related to the highest internalization of values: adolescents from authoritative and indulgent households (both characterized by high acceptance/involvement) give higher priority to the values analyzed, whereas adolescents from authoritarian and neglectful parents (both characterized by low acceptance/involvement) generally assign the lowest priority to these values. Although authoritative parenting is also characterized by a high level of strictness/imposition and indulgent parenting is characterized by low levels of strictness/imposition, it seems that the use of these practices -strictness and imposition- is not related with either more or less internalization of self-transcendence and conservation values of Spanish' adolescents. In consequence, it seems that the internalization of these social values by adolescents is primarily defined by the degree of acceptance/involvement utilized by the parents. However, adolescents' academic and family selfesteem appears to be negatively influenced by the degree of strictness/imposition utilized by parents. Although adolescents from indulgent and authoritative parents (both characterized by high use of acceptance/involvement) have the highest scores in these self-esteem dimensions, adolescents from authoritative parents (who are also characterized by high levels of strictness/imposition) have lower academic and family selfesteem than adolescents from indulgent parents (whose use of strictness/imposition is low). Furthermore, adolescents from authoritarian parents (characterized by low acceptance/ involvement and high strictness/imposition) obtain the worst results.

Moreover, we confirmed that the association of parenting styles with self-esteem and internalization of values is not influenced by the control variables of the study (adolescents' gender, age, and type of school). We also confirmed that the relationship of these demographic variables with the self-esteem and the value priorities of Spanish adolescents is consistent with the results reported in the literature (Garaigordobil et al., 2005; García \& Musitu, 1999; Grotevant \& Cooper, 1998; Insa, 2003; Molpeceres, 1996).

In short, the study shows that the association between authoritative parenting and optimum outcomes in offspring reported in studies on European-American families in the United States, is not confirmed in Spanish adolescents when self-esteem or interiorization of self-transcendence and conservation values are used as outcome variables. On the contrary, the results support studies that question the generalization of the association between authoritative parenting and optimum adjustment to any ethnic or cultural context (Dornbusch et al., 1987; Chao, 2001; Kim \& Rhoner, 2002; Steinberg et al., 1991). Particularly, the present study reinforces previous research in Spain (Musitu \& García, 2004) and in some countries such as Italy (Marchetti, 1997), Mexico (Villalobos et al., 2004), and Brazil (Martínez et al., 2003; Martínez, García, \& Yubero, 2007), which has found that, in these cultures, indulgent parenting is associated with the same or better adolescent outcomes than authoritative parenting.

To explain why authoritative parenting is not associated with better outcomes in adolescents in all cultural-ethnic contexts, it has been argued that some parenting practices can have different meanings depending on the characteristics of the culture (Chao, 2001) and can be associated with different parenting objectives (Rao, McHale, \& Pearson, 2003). Therefore, the impact of parenting styles on offspring can vary in different cultures. In this sense, it has been argued that authoritarian practices have a positive impact on collectivistic Asiatic cultures because, in those contexts, strict discipline is understood as beneficial for the children (Grusec et al., 1997) and because both parents and children view authoritarian practices as an organizational strategy that fosters harmony within the family and tries to ensure children's morals (Chao 1994; Ho, 1989). On the other hand, in Spain, Italy, and Latin American countries, such as Mexico and Brazil, it seems that more emphasis is placed on the use of affection, acceptance, and involvement in children's socialization (Musitu \& García, 2004; Villalobos et al., 2004). Furthermore, Spain has been characterized as a horizontal collectivist country (Gouveia et al., 2003). In contrast to vertical individualist (e.g., United States) and vertical collectivistic (e.g., some Asiatic countries) cultures, which are based on hierarchical relations, in horizontal collectivist cultures, equalitarian relations are emphasized (Triandis, 1995, 2001). As Rudy and Grusec (2001) pointed out, strict practices seem to be perceived in a negative way in cultures that are not based on hierarchical relationships. As a result, strictness practices, which involve a hierarchical parentchild relationship, do not seem to have a positive influence on the socialization of offspring in Spain, whereas practices such as affection, reasoning, acceptance, and involvement are positively related to adolescents' outcomes. 
This research is an important contribution to parenting studies because it shows that the association of authoritative parenting with positive developmental outcomes, observed in the United States on European-American families, cannot be fully generalized to the Spanish cultural context. Furthermore, we point out some specific characteristics of the Spanish culture that can explain the relations between parenting styles and adolescent's outcomes in Spain. However, further examination of the meaning of parenting styles and their association with different outcomes of the adolescent in Spain is warranted in order to increase knowledge of the link between parenting and adolescent adjustment in this country. Finally, with regards to the methodology employed in this study, two considerations should be taken into account. First, the study was a crosssectional one that did not provide the possibility to test causal hypotheses. Therefore, in the absence of longitudinal or experimental data, these findings must be viewed as preliminary. Second, results may have been influenced by the fact that the teenagers reported their parents' behavior, even though some authors in parenting research have found similar results when parents carried out the assessment themselves (Aunola et al., 2000; Kim, 2001). In any case, it is clear that the relationship between parenting styles and adolescent outcomes presents cultural differences that will need to be further taken into consideration in future research.

\section{References}

Aluja, A., del Barrio, V., \& García, L.F. (2005). Relationships between adolescents' memory of parental rearing styles, social values and socialisation behavior traits. Personality and Individual Differences, 39, 903-912.

Amato, P.R., \& Fowler, F. (2002). Parenting practices, child adjustment, and family diversity. Journal of Marriage and the Family, 64, 703-716.

Aunola, K., Stattin, H., \& Nurmi, J.E. (2000). Parenting styles and adolescents' achievement strategies. Journal of Adolescence, 23, 205-222.

Barber, B.K. (1990). Marital quality, parental behaviors, and adolescent self-esteem. In B.K. Barber, \& B.C. Rollings (Eds.), Parent-adolescent interaction (pp. 49-74). Lanham, MD: University Press of America.

Barber, B.K., Chadwick, B.A., \& Oerter, R. (1992). Parental behaviors and adolescent self-esteem in the United States and Germany. Journal of Marriage and the Family, 54, 128-141.

Baumrind, D. (1966). Effects of authoritative parental control on child behavior. Child Development, 37, 887-907.

Baumrind, D. (1978). Reciprocal rights and responsibilities in parent-child relations. Journal of Social Issues, 34, 179-196.

Baumrind, D. (1983). Rejoinder to Lewis' reinterpretation of parental firm control effects: Are authoritative families really harmonious? Psychological Bulletin, 94, 132-142.
Baumrind, D. (1989). Rearing competent children. In W. Damon (Ed.), Child development today and tomorrow (pp. 349-378). San Francisco: Jossey-Bass.

Baumrind, D. (1991). The influence of parenting style on adolescent competence and substance use. The Journal of Early Adolescence, 11, 56-95.

Bersabé, R., Fuentes, M. J., \& Motrico, E. (2001). Análisis psicométrico de dos escalas para evaluar estilos educativos parentales. Psicothema, 13, 678-684.

Byrne, B.M., \& Shavelson, R.J. (1996). On the structure of social self-concept for pre-, early, and late adolescents: A test of the Shavelson, Hubner, and Stanton (1976) model. Journal of Personality and Social Psychology, 70, 599-613.

Cava, M. J., Musitu, G., \& Murgui, S. (2006). Familia y violencia escolar: El rol mediador de la autoestima y la actitud hacia la autoridad institucional. Psicothema, 18, 367-373.

Chao, R.K. (1994). Beyond parental control and authoritarian parenting style: Understanding Chinese parenting through the cultural notion of training. Child Development, 65, 1111-1119.

Chao, R.K. (2001). Extending research on the consequences of parenting style for Chinese Americans and European Americans. Child Development, 72, 1832-1843.

Coopersmith, S. (1967). The antecedents of self-esteem. San Francisco: Freeman.

Darling, N., \& Steinberg, L. (1993). Parenting style as context: An integrative model. Psychological Bulletin, 113, 487-496.

Dornbusch, S. M., Ritter, P. L., Leiderman, P. H., Roberts, D. F., \& Fraleigh, M. J. (1987). The relation of parenting style to adolescent school performance. Child Development, 58, 12441257.

Dwairy, M., Achoui, M., Abouserfe, R., \& Farah, A. (2006). Parenting styles, individuation, and mental health of Arab adolescents: A third cross-regional research study. Journal of Cross-Cultural Psychology, 37, 262-272.

Erdfelder, E., Faul, F., \& Buchner, A. (1996). GPOWER: A general power analysis program. Behavior Research Methods Instruments \& Computers, 28, 1-11.

Feldman, S.S., \& Rosenthal, D.A. (1991). Age expectations of behavioural autonomy in Hong Kong, Australian and American youth: The influence of family variables and adolescents' values. International Journal of Psychology, 26, 1-23.

Felson, R.B., \& Zielinski, M.A. (1989). Children's self-esteem and parental support. Journal of Marriage and the Family, 51, 727735.

Garaigordobil, M., Durá, A., \& Pérez, J.I. (2005). Psychopathological symptoms, behavioural problems, and selfconcept/self-esteem: A study of adolescents aged 14 to 17 years old. Annuary of Clinical and Health Psychology, 1, 53-63.

García, J.F., Frías, M.D., \& Pascual, J. (1999). Los diseños de la investigación experimental: Comprobación de las hipótesis. Valencia, Spain: Cristóbal Serrano Villalba.

García, J. F., \& Musitu, G. (1999). AF5: Autoconcepto forma 5. Madrid: TEA.

García, J.F., Musitu, G., \& Veiga, F. (2006). Autoconcepto en adultos de España y Portugal. Psicothema, 18, 551-556. 
Gecas, V., \& Schwalbe, M.L. (1986). Parental behavior and adolescent self-esteem. Journal of Marriage and the Family, 48, 37-46.

Gouveia, V.V., Clemente, M., \& Espinosa, P. (2003). The horizontal and vertical attributes of individualism and collectivism in a Spanish population. Journal of Social Psychology, 143, 43-63.

Grotevant, H.D., \& Cooper, C.R. (1998). Individuality and connectedness in adolescent development: Review and prospects for research on identity, relationships, and context. In E.E.A. Skoe \& A.L. van der Lippe (Eds.), Personality development in adolescence: A cross national and life span perspective. Adolescence and society (pp. 3-37). London: Routledge.

Grusec, J.E., \& Goodnow, J.J. (1994). Impact of parental discipline methods on the child's internalization of values: A reconceptualization of current points-of-view. Developmental Psychology, 30, 4-19.

Grusec, J.E., Goodnow, J.J., \& Kuczynski, L. (2000). New directions in analyses of parenting contributions to children's acquisition of values. Child Development, 71, 205-211.

Grusec, J.E., Rudy, D., \& Martini, T. (1997). Parenting cognitions and child outcomes: An overview and implications for children's internalization of values. In J. E. Grusec \& L. Kuczynski (Eds.), Parenting and children's internalization of values: A handbook of contemporary theory (pp. 259-282). New York: Wiley.

Gual, P., Pérez-Gaspar, M., Martinez-Gonzalez, M.A., Lahortiga, F., de Irala-Estevez, J., \& Cervera-Enguix, S. (2002). Selfesteem, personality, and eating disorders: Baseline assessment of a prospective population-based cohort. International Journal of Eating Disorders, 31, 261-273.

Ho, D.Y.F. (1989). Continuity and variation in Chinese patterns of socialization. Journal of Marriage and the Family, 51, 149-163.

Insa, L.L. (2003). Las prioridades de valor en la adolescencia: Diferencias en función del sexo y la edad. Informació Psicológica, 81, 55-62.

Kalton, G. (1983). Introduction to survey sampling. Beverly Hills, CA: Sage.

Kelley, M.L., Power, T.G., \& Wimbush, D.D. (1992). Determinants of disciplinary practices in low-income black mothers. Child Development, 63, 573-582.

Kerlinger, F.N. (1973). Foundations of behavioral research $\left(2^{\text {nd }}\right.$ ed.).New York: Holt, Rinehart, \& Winston.

Kim, E. (2001). Korean American parent-child relationships, acculturation, and young adolescents' psychosocial functioning. Unpublished doctoral dissertation, University of WisconsinMadison.

Kim, K., \& Rohner, R.P. (2002). Parental warmth, control, and involvement in schooling: Predicting academic achievement among Korean American adolescents. Journal of Cross-Cultural Psychology, 33, 127-140.

Kremers, S.P., Brug, J., de Vries, H., \& Engels, R.C.M.E. (2003). Parenting style and adolescent fruit consumption. Appetite, 41, 43-50.

Lamborn, S.D., Mounts, N.S., Steinberg, L., \& Dornbusch, S.M. (1991). Patterns of competence and adjustment among adolescents from authoritative, authoritarian, indulgent, and neglectful families. Child Development, 62, 1049-1065.
Lewis, C.C. (1981). The effects of parental firm control: A reinterpretation of findings. Psychological Bulletin, 90, 547563.

Llinares, L. (1998). La configuración del autoconcepto y los valores en el contexto familiar. Unpublished doctoral dissertation, University of Valencia, Spain.

Maccoby, E.E., \& Martin, J.A. (1983). Socialization in the context of the family: Parent-child interaction. In P.H. Mussen (Ed.), Handbook of child psychology (Vol. 4, pp. 1-101). New York: Wiley.

MacDonald, K. (1997). The coherence of individual development: An evolutionary perspective on children's internalization of parental values. In J.E. Grusec, \& L. Kuczynski (Eds.), Parenting and children's internalization of values: A handbook of contemporary theory (pp. 362-397). New York: Wiley.

Marchetti, B. (1997). Concetto di se'relazioni familiari e valori. Unpublished master's thesis, Universita degli Studi di Bologna, Italy.

Martínez, I. (2003). Estudio transcultural de los estilos de socialización parental. Unpublished doctoral dissertation, University of Valencia, Spain.

Martínez, I., García, J.F., \& Yubero, S. (2007). Parenting styles and adolescents' self-esteem in Brazil. Psychological Reports, 100, 731-745.

Martínez-González, M.A., Gual, P., Lahortiga, F., Alonso, Y., de Irala-Estevez, J., \& Cervera, S. (2003). Parental factors, mass media influences, and the onset of eating disorders in a prospective population-based cohort. Pediatrics, 111, 315-320.

Martínez, I., Musitu, G., García, J.F., \& Camino, L. (2003). Un análisis intercultural de los efectos de la socialización familiar en el autoconcepto: España y Brasil. Psicologia Educação Cultura, 7, 239-259.

Maxwell, S.E., \& Delaney, H.D. (1990). Designing experiments and analyzing data: A model comparison perspective. Belmont, CA: Wadsworth.

Mayseless, O., Scharf, M., \& Sholt, M. (2003). From authoritative parenting practices to an authoritarian context: Exploring the person-environment fit. Journal of Research on Adolescence, 13, 427-456.

Molpeceres, M.A. (1996). El sistema de valores: Su configuración cultural y su socialización familiar en la adolescencia. Unpublished doctoral dissertation, University of Valencia, Spain.

Musitu, G., \& García, F. (2001). ESPA29: Escala de estilos de socialización parental en la adolescencia. Madrid, Spain: TEA.

Musitu, G., \& García, J.F. (2004). Consecuencias de la socialización familiar en la cultura española. Psicothema, 16, 288-293.

Pels, T., \& De Haan, M. (2007). Socialization practices of Moroccan families after migration: A reconstruction in an 'acculturative arena.' Young, 15, 71-89.

Quoss, B., \& Zhao, W. (1995). Parenting styles and children's satisfaction with parenting in China and the United States. Journal of Comparative Family Studies, 26, 265-280.

Rao, N., McHale, J.P., \& Pearson, E. (2003). Links between socialization goals and child-rearing practices in Chinese and Indian mothers. Infant and Child Development, 12, 475-492. 
Roccas, S., Sagiv, L., Schwartz, S.H., \& Knafo, A. (2002). The big five personality factors and personal values. Personality and Social Psychology Bulletin, 28, 789-801.

Rodd, J. (1996). Socialization attitudes and practices of Korean mothers of young children: The influence of context. In E. Hujala (Ed.), Childhood education: International perspectives (pp. 63-73). Oulu University, Finland: Finland Association for Childhood Education International.

Rosenberg, M. (1965). Society and the adolescent self-image. Princeton, NJ: Princeton University Press.

Rothenberg, D. (1997). Supporting girls in early adolescence. Washington, DC: Office of Educational Research and Improvement.

Rudy, D., \& Grusec, J.E. (2001). Correlates of authoritarian parenting in individualist and collectivist cultures and implications for understanding the transmission of values. Journal of Cross-Cultural Psychology, 32, 202-212.

Rudy, D., \& Grusec, J.E. (2006). Authoritarian parenting in individualist and collectivist groups: Associations with maternal emotion and cognition and children's self-esteem. Journal of Family Psychology, 20, 68-78.

Sagiv, L., \& Schwartz, S.H. (2000). Value priorities and subjective well-being: Direct relations and congruity effects. European Journal of Social Psychology, 30, 177-198.

Schwartz, S.H. (1992). Universals in the content and structure of values: Theoretical advances and empirical tests in 20 countries. In M.P. Zanna (Ed.), Advances in experimental social psychology (Vol. 25, pp. 1-65). New York: Academic Press.

Schwartz, S.H. (1994). Are there universal aspects in the structure and contents of human values? Journal of Social Issues, 50, $19-45$.

Schwartz, S.H. (2005). Basic human values: Their content and structure across countries. In A. Tamayo \& J.B. Porto (Eds.), Valores e comportamento nas organizações (pp. 21-55). Petrópolis, Brazil: Vozes.

Schwartz, S.H., \& Bardi, A. (2001). Value hierarchies across cultures: Taking a similarities perspective. Journal of CrossCultural Psychology, 32, 268-290.

Schwartz, S.H., \& Bilsky, W. (1987). Toward a universal psychological structure of human-values. Journal of Personality and Social Psychology, 53, 550-562.

Schwartz, S.H., \& Bilsky, W. (1990). Toward a theory of the universal content and structure of values: Extensions and cross- cultural replications. Journal of Personality and Social Psychology, 58, 878-891.

Schwartz, S.H., \& Sagiv, L. (1995). Identifying culture-specifics in the content and structure of values. Journal of Cross-Cultural Psychology, 26, 92-116.

Shavelson, R.J., Hubner, J.J., \& Stanton, G.C. (1976). Self-concept: Validation of construct interpretations. Review of Educational Research, 46, 407-441.

Smetana, J. G. (1995). Parenting styles and conceptions of parental authority during adolescence. Child Development, 66, 299-316.

Steinberg, L., Dornbusch, S.M., \& Brown, B.B. (1992). Ethnicdifferences in adolescent achievement: An ecological perspective. American Psychologist, 47, 723-729.

Steinberg, L., Lamborn, S.D., Darling, N., Mounts, N.S., \& Dornbusch, S.M. (1994). Over-time changes in adjustment and competence among adolescents from authoritative, authoritarian, indulgent, and neglectful families. Child Development, 65, 754770 .

Steinberg, L., Mounts, N.S., Lamborn, S.D., \& Dornbusch, S.M. (1991). Authoritative parenting and adolescent adjustment across varied ecological niches. Journal of Research on Adolescence, 1, 19-36.

Struch, N., Schwartz, S.H., \& van der Kloot, W.A. (2002). Meanings of basic values for women and men: A cross-cultural analysis. Personality and Social Psychology Bulletin, 28, 16-28.

Tomás, J.M., \& Oliver, A. (2004). Análisis psicométrico confirmatorio de una medida multidimensional del autoconcepto en español. Revista Interamericana de Psicología, 38, 285-293.

Triandis, H.C. (1995). Individualism and collectivism. Boulder, CO: Westview Press.

Triandis, H.C. (2001). Individualism-collectivism and personality. Journal of Personality, 69, 907-924.

Villalobos, J.A., Cruz, A.V., \& Sánchez, P.R. (2004). Estilos parentales y desarrollo psicosocial en estudiantes de Bachillerato. Revista Mexicana de Psicología, 21, 119-129.

Wahler, R.G., \& Cerezo, M.A. (2005). The mothering of conduct problem and normal children in Spain and the USA: Authoritarian and permissive asynchrony. The Spanish Journal of Psychology, 8, 205-214.

Received November, 22, 2006 Revision received February, 20, 2007 Accepted June, 30, 2007 